\title{
Símbolos en la ciudad: la caravana de los animales ${ }^{1}$
}

\section{UNA ROMERÍA URBANA}

El viandante que pasee por las céntricas calles de Hortaleza, Barceló, o Fuencarral, en Madrid, un diecisiete de enero - a eso de las seis de la tarde-, habrá de verse sorprendido, al tratar de cruzar la calle, por el paso de un camello, una batahola de perros ladrando, guiados por sus dueños, o un cerdo gigantesco. Deteniéndose un momento tras las vallas que cortan el tráfico, escuchará los comentarios, divertidos o intrigados, de otros espectadores. "CCómo flipan!” „Es que no veas si vienen caballos ni ná!» "Pero esto qué es!" "¿Qué significa esto?» "Mira, un cerdo; ¿nos lo comemos con patatitas?" "Viene un gorrino así de alto, te lo juro".

La romería de San Antón, patrón de los animales (y, particularmente, de los ganados de cerda), es, para muchos, un acontecimiento sorprendente y curioso en el Madrid de hoy. Viola radicalmente nuestra expectativa ordinaria sobre el uso del espacio urbano, cediéndolo temporalmente a una cabalgata de perros, gatos, canarios, caballos y tortugas. No es habitual ver a estos animales pasear por las calzadas (ni aun acompañados por sus propietarios). Es de esta pequeña transgresión de donde deriva buena parte de la diversión y del sentido de fiesta que uno puede percibir en la sonrisa amable de todos los participantes.

La festividad de San Antón (San Antonio Abad) se celebra dando tres vueltas alrededor de la parroquia que lleva su nombre. Con su hisopo, el párroco bendice los animales rociándolos de agua, para mantenerlos con salud. En el interior de la iglesia se adora la reliquia del santo, y por una puerta lateral se venden sus "panecillos", unos dulces asimismo bendecidos. Este es el núcleo de acciones estipuladas por la tradición. El actual programa de fiestas, soportado económicamente por la Junta de Distrito del

1 Escrito con ayuda de la Consejería de Educación de la Comunidad de Madrid, programa "Evolución de los rituales festivos de la Comunidad de Madrid: análisis comparativo entre una zona rural y otra urbana" (H002-91), y presentado en el curso "El estudio antropológico de los procesos cognitivos y simbólicosn, Universidad de Granada, Septiembre 1992. En la producción de este análisis debo hartas sugerencias a Honorio Velasco, Angel Díaz de Rada y Jesús Martín-Barbero. Las fotos son de Maritza Guadarrama. 
Ayuntamiento, comienza unos días antes del de la celebración. Incluye pregón, una conferencia, algún concierto de música clásica en el recinto de la iglesia, una "diana" para avisar a los vecinos en la mañana del día diecisiete. Además, la parroquia organiza una novena y misa mayor, concelebrada.

La fiesta ha sufrido una larga historia de transformaciones a través de las cuales resulta visible el proceso de urbanización y racionalización de la vida local. Sus distintas formas han tenido que adaptarse, por un lado, a la normalización impuesta por las autoridades estatal, municipal y eclesiástica, y, por otro, a cambios de fondo en el tejido de la ciudad misma. Tal y como hoy la vemos -y como yo la presentaré en mi etnografía-, es un producto reciente; forma parte del proceso de "recuperación" o "revitalización" de fiestas y tradiciones locales que acompañó, a comienzos de los años ochenta, el ascenso de los primeros gobiernos municipales de izquierda.

Siguiendo a folcloristas e historiadores, podemos resumir dicha trayectoria de la manera que sigue ${ }^{2}$. El antecedente directo de la romería, establecida en el XviII, fue una fiesta grotesca en la que los porqueros de la villa elegían un rey de los cerdos y un rey de los porqueros. Resultaba rey entre los puercos, ataviados ese día con cintas y campanillas, el que ganaba a los demás en la carrera hasta una artesa llena de comida. El cargo de rey de los porqueros era sorteado entre los más jóvenes de la profesión:

\begin{abstract}
...al que designaba la suerte, se le vestía de San Antón, dándole un báculo por cetro y una campanilla que tocaba a cada instante, y montándosele en un burro, el más viejo y matalón que se hallaba, al que se adornaba de sartas de ajos y de otras frutas extravagantes, como nabos, zanahorias, etc., se le conducía en triunfo a la ermita de San Antonio... Rompían la procesión porción de mozos del campo montados en encintados borricos, tocando unos roncos cuernos adornados con lazos de varios colores, y con caperuzas puntiagudas por sombreros; después seguian los porqueros, conduciendo, atados de dos en dos, seis cerdos llenos de cascabeles y campanillas; detrás iban los machos de las piaras, con unos grandes esquilones al pescuezo, y montados en ellos mozos vestidos con disfrazes ridículos; seguian luego los barracos de la villa, con reposteros o mantillas muy lujosas, acompañando al rey de los cerdos, que había salido en la carrera, el cual llevaba una corona de ajos y guindillas; y seguía a éste el porquero vestido de San Antón, que llevaba por escolta una porción de chusma montada en borricos y haciendo un ruido infernal con cencerros, cuernos y tambores ${ }^{3}$.
\end{abstract}

2 Para esta breve reconstrucción me he servido de distintas fuentes - que refieren en ocasiones unas a otras, aunque sin citarse-: Julio CARO BAROJA, El carnaval. Análisis histórico-cultural (Madrid: Taurus, 1986); Francisco AZORIN, El Madrid devoto y romero (Madrid: El Avapiés, 1984); Pedro MONTOLIU CAMPS, Fiestas y tradiciones madrileñas (Madrid: Sílex, 1990).

3 Sebastián de Castellanos, citado en J. Caro Baroja, op. cit., p. 337. 
A este joven trasunto del santo, tocado con barba postiza y un manto de estera pintarrazada", se le montaba sobre el cerdo-rey y se le coronaba rey de los cochinos con la misma corona de ajos y guindillas que momentos antes lucía puesta el animal. Se desplazaban entonces a la iglesia de San Antón, donde, por intermedio de su rey, solicitaban a los religiosos la bendición para la cebada y la paja que llevaban como alimento de sus ganados; y para los panecillos que aquéllos habían preparado, marcados por los símbolos del santo: el báculo con la letra tau, un cerdo con una campanilla, o la campanilla sola. La celebración se prolongaba luego hasta altas horas, con hogueras y bailes.

Paradójicamente, conocemos estos hechos a través de las provisiones y disposiciones dictadas durante los siglos XVII y XVIII para restringirlos, reprimirlos o modificarlos: un bando de 1619 "disponiendo que la fiesta se celebrara fuera de la villa"; otro de 1697 "prohibiéndola terminantemente"; el mismo, repetido en 1722 "por no haber hecho caso de su publicación anterior" ". Años más tarde volvería a ser permitida, pero ya limitada a la romería y la bendición.

Hacia 1725 se reanudó la costumbre de bendecir panes, cebada y animales, si bien estos últimos dejaron de atravesar la ciudad. En tiempos de Bonaparte se interrumpió de nuevo, para alcanzar un gran auge, según P. Montoliú, durante el reinado de Isabel II, con embotellamientos de carruajes en torno al templo, charangas, presencia de los famosos de la época y reseñas en los periódicos. Fue por entonces cuando la masiva afluencia de público obligó a fijar un amplio itinerario de varias manzanas en torno a la iglesia para la realización de las vueltas.

La pintura que la literatura de costumbres hace de la romería hasta la época de la República y la Guerra Civil es la de unos romeros que conducen sus caballerías, adornadas con flores de papel y cencerros al cuello, en un entorno de guirnaldas, farolillos, puestos de venta ambulante y golosinas verbeneras. Una imagen que contrasta considerablemente con los intentos de reactivación de la fiesta durante la posguerra, a partir de los años cuarenta. Al grueso de la caravana, formada esta vez por perros y gatos, se incorporaron elementos como un pregón, algunos animales del circo Price, los alumnos de las escuelas hípicas y la Guardia de Franco. A finales de los sesenta se suspendieron las vueltas, para evitar el corte del tráfico, aunque se siguiera bendiciendo a los animales desde la ventana exterior de la parroquia 5

Es bien conocido el proceso de reactivación de las fiestas que, a finales de los años setenta y comienzos de los ochenta, se asoció, en Madrid y

4 J. Caro Baroja, op. cit., p. 338.

5 P. Montoliu, op. cit., p. 46. 
en toda España, al advenimiento de las primeras administraciones municipales democráticas. En el caso madrileño, ya desde el último gobierno municipal de UCD resulta perceptible (por ejemplo, en la prensa de la época) ese interés por lo que entonces se llamó "la recuperación". Primero obtuvieron resonancia algunas fiestas de barrio, como las del Dos de Mayo en Malasaña, o las de Vallecas. Luego, se consiguió ampliar y dar relieve a las patronales de San Isidro. A continuación aparecieron los Carnavales, las fiestas de los distintos distritos, los Veranos de la Villa, las Fiestas de la Comunidad... En 1983 el alcalde Tierno Galván leía el pregón de San Antón, facilitando en 1985 el corte de calles para hacer las "vueltas". En cada uno de esos casos el proceso fue diferente. Algunas celebraciones tuvieron su origen en una intensa actividad de organizaciones cívicas y vecinales, más o menos combativas políticamente. Otras fueron diseñadas enteramente ex nibilo por técnicos y responsables municipales. Cada distrito se proveyó, en cualquier caso, de una estructura administrativa que garantizara una cierta presencia de los administrados en la gestión de sus fiestas".

La romería de San Antón se organiza de manera conjunta desde la parroquia, sede tradicional de su liturgia y sus símbolos, y la Junta Municipal correspondiente, que es la del Distrito Centro. En su reanudación ha intervenido de manera estelar el párroco, un hombre con carisma en el barrio y empeñado personalmente en sacarla adelante. Hay que contar también con la continuidad de la devoción vecinal a lo largo de los años, $y$, por supuesto, con el proceso general de institucionalización festiva que venimos comentando, y del cual es buena muestra la creciente intervención del Ayuntamiento en la preparación y desarrollo de la fiesta.

El ritual del que voy a hablar es, por tanto, a la vez muy nuevo y muy viejo. Es muy nuevo porque forma parte de un proceso político y social reciente que ha resignificado drásticamente, en el plazo de unos pocos años, toda actividad pública festiva y su ocupación de las calles, convirtiéndolas en un ejercicio de ciudadanía. Es muy viejo, porque, ciertamente, a San Antón (y a su cerdo) se los celebra en la ciudad desde tiempos remotos. Pero aún más que por eso, es viejo porque cuantos quieren

\footnotetext{
6 Si bien el caso espanol posee facetas propias, conectadas principalmente con la transición política y la instauración de administraciones autonómicas, esta reactivación temente de expla ha sido general en toda Europa. J. Boissevain ha tratado recienmodernización la explor sus causas, destacando sobre todo las reacciones locales a la modernización, la emigración, la pérdida de poder de las instituciones eclesiásticas, y un progresivo protagonismo del juego sobre el ritual Revitalizing european rituals (Londres: Routledge, 1992).
} 
"reverdecer las costumbres" -en palabras del cura párroco- tienen como referencia obligada, precisamente, esa lejanía temporal. Aun cuando se trate de una antiguedad estipulada, pretendida, la tradición y sus imágenes les proporcionan un buen modelo de acción y de representación; en particular, de acción simbólica y de representación de la continuidad social. Un modelo, desde luego, interpretado y apropiado desde la modernidad y por agentes sociales modernos. En ese sentido, la tradición no es ya el modelo único, si es que realmente lo ha sido alguna vez. Es sencillamente uno más, en imbricada madeja con otros modelos a los que sociólogos, antropólogos y economistas nos hemos venido refiriendo de modo diverso como "acción estratégica", "racionalidad instrumental", "cálculo maximizador", "lógica burocrática", "procedimientos técnicos", etc.

Espero poder mostrar que la tradición, si se la concibe como un proceso de sujeción a convenciones compartidas, tiene un lugar entre todas esas categorías, que son en buena medida las definitorias de la modernidad; y un lugar de importancia. De modo que en lo que sigue veremos, sorprendentemente, regresar desde el fondo de la calle de Hortaleza al cerdo de San Antón; si bien en la versión edulcorada y risueña que le permite una sociedad urbana, moderna e ilustrada como la nuestra. Una sociedad que se quiere y se cree despojada de los tonos ácidos y la violenta descompostura de aquel fascinante rey de los cochinos.

\section{LA CABALGATA DE LOS ANIMALES}

"La cabalgata de los animales" es el encabezamiento con que una reseña periodística aludía recientemente a la romería. Los medios escritos - no sólo la prensa, sino, en general, la cultura libresca- son un elemento de peso en recrearla y conformarla. No es sólo que el párroco y otros agentes activos muestren interés por "documentar" históricamente la fiesta y ajustarla a la tradición. Es que documentarse es parte de la fiesta misma, una actividad festiva entre otras. Para el pregón y la conferencia se acude a "personajes de alturaw: Mingote, el alcalde Tierno, Gutiérrez Mellado, cronistas de la Villa, escritores, periodistas. En palabras del párroco, «se intenta que la fiesta no sea simplemente una fiesta, sino que sea cultura. Que sea educativa para el pueblo".

La presentación del programa, el día quince de Enero, tiene aires de performance institucional. La iglesia está llena a medias, por ancianos del barrio. En la puerta, los organizadores del equipo de gobierno de la Junta Municipal hacen tiempo, esperando la llegada del Concejal y el Alcalde; también los fotógrafos y la policía. El padre Villar, cura párroco, da vueltas 
de un lado a otro, disponiéndolo todo. En la familiaridad, a veces un poco irreverente, con que se dirige a la autoridad civil se percibe que se siente en su terreno: en su parroquia, en su fiesta. Protocolariamente, el Alcalde llega el último; también es corriente que se marche el primero. Se hace a la entrada la foto de rigor con el párroco y el pregonero, avanzando a continuación por el pasillo central hasta el altar mayor transformado en mesa de autoridades. La disposición es jerárquica.

El pregonero, naturalmente de traje, en una esquina y flanqueado por las banderas de España, la Comunidad y el Ayuntamiento, habla durante media hora de los problemas de la vida en la ciudad (el tráfico, la deshumanización, el paro, la violencia, la contaminación), invocando la necesaria protección del santo. Aprovecha la polisemia de "caballo", "camello", y "mono" para hablar del mundo de la droga. Mediante una analogía animal, nos representa una sociedad de "borregos" y "lobos", "cuervos" y "palomas". Es éste un tema recurrente que he escuchado en varias ocasiones. Pero los pregoneros tienen libertad para elegir el tema de su preferencia. El padre Villar les facilita, a modo de guía, los pregones de años anteriores. Al finalizar el pregonero, se le entrega una panorámica enmarcada de la Plaza Mayor. Posando para los fotógrafos, el Alcalde mira hacia el proscenio, sonriente, mostrando este regalo institucional que se viene repitiendo en los últimos años. Antes de retirarse, besa públicamente la reliquia del santo. El párroco bromed hacia la audiencia: "Es para que bendiga a todos los animales, ¿eh?"?.

Esta actitud desenfadada, jocosa, del cura se acentúa, si cabe, el día de la fiesta, salpicando con agua bendita a sus feligreses, entre bendición y bendición de perros y gatos; diciendo «ilos hombres somos animales... racionales!n. haciendo bromas a los niños, hablando con los animales que se resisten a dejarse bendecir. A lo largo de la mañana se bendice desde la capillita que da a la calle, con una imagen de San Antón rodeada de flores y velas. El santo lleva en una mano un libro, a sus pies tiene un cerdito con

Como puede apreciarse en este punto, el estilo descriptivo que he decidido adoptar es el caracterizado por Rosaldo como "realismo etnográficon: "...una amalgama de observaciones y entrevistas repetidas, que intenta perfilar un acontecimiento al mismo tiempo como específico de, y como general en, una particular forma de vida. Tales relatos agrupan materiales dispares, confiando en que el patrón que revelan represente la forma universal.... La inclusión de particularidades casuales e irrepetibles, como la actuación de un pregonero en concreto, resulta no obstante necesaria en nuestro caso para recuperar algo de la viveza y el sentido suspensivo de acontecer temporal que se da en toda fiesta, y que tan bien sabe recoger la narrativa novelística. Ver Renato Rosaldo, "Ilongot Hunting as Story and Experience", The anthropology of experience, eds. Victor W. TURNER y Edward M. BRUNER (Urbana y Chicago: University of Illinois Press, 1986), p. 100. 


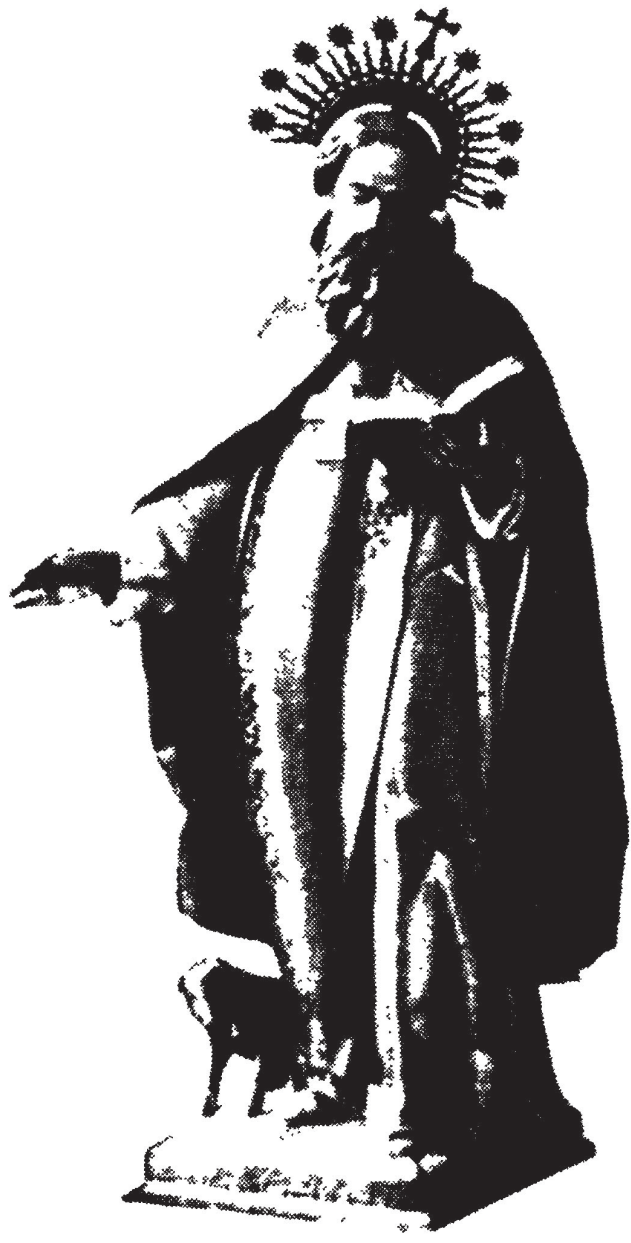

FIG. 1.-Una de las imágenes del Santo que hay en la parroquia. una campanilla al cuello ${ }^{8}$. Las personas se acercan con sus animales de compañía, a menudo tomándolos en brazos para que no puedan escabullirse. A veces vienen con alguna otra persona con el fin de que les tire una foto, de modo que fotógrafos, periodistas $y$ mirones nos vamos arracimando frente a la capilla. El cura recita siempre la misma oración: "Reciban, Señor, tu bendición estos animales con la cual sean salvos en el cuerpo y por la intercesión de San Antonio, se vean libres de todo mal". Los dueños dan el "amén"; algunos ofrecen limosna. Hay sonrisas y comentarios en voz alta, sobre todo cuando los bichos se asustan. "ile tienen miedo al agua!n "No les gusta a ellos, no". "Es ló g i CO". "Ni bendi-

ciéndose se está quieta". "Pues menos mal que no le echa un viaje a la mano...".

En la calle lateral de la iglesia se venden los panecillos. Poniéndose a la cola y haciéndose un poco el tonto, el etnógrafo recaba algunas explicaciones, dadas con profusión y entre sonrisas. Según unos, los panecillos son "para los perros", y se compran porque "están benditos". Según otros, "son para comer

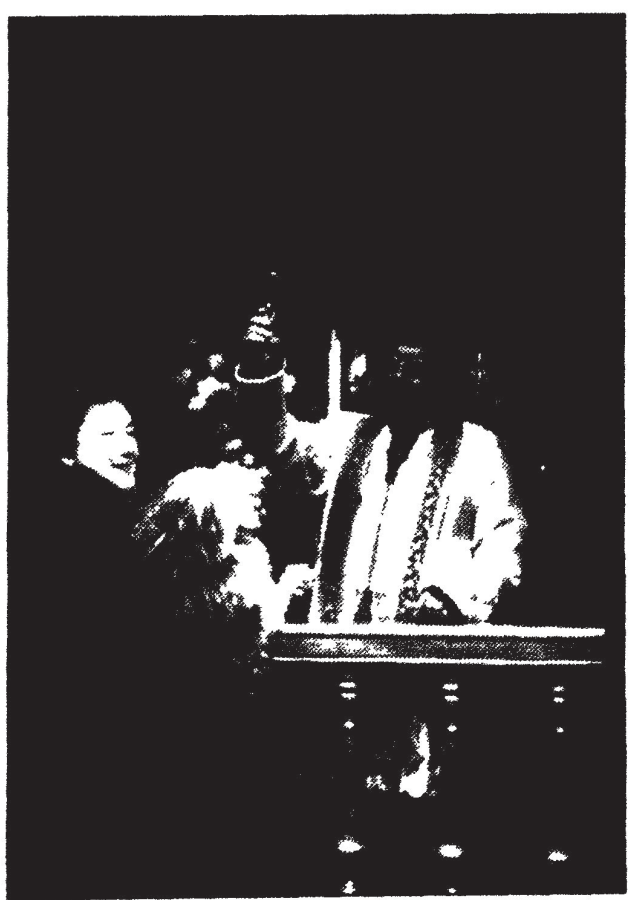

FIG. 2.-Los animales son bendecidos individualmente desde una capillita que da a la calle.

8 Esta es sólo una de las formas iconográficas de representar a San Antón, si bien la preferida por los fieles. Preguntado por la importancia de la reliquia y las imágenes del santo en el culto, comenta el padre Villar: "El papel que juega la reliquia, ninguno, que la gente se ve como más cerca de San Antón... El Santo más que otra cosa es lo que se llama hoy los medios audiovisuales, el Santo es como visualizar algo que quieres ver... A la gente le gusta siempre ver a San Antón con el cerditon. 
las personas", "son como el suizo", "una especie de galleta dura", "para mojar en el café. (de hecho, es posible ver comiéndolos tanto a los animales como a sus amos). Se compran "porque es cosa de toda la vida", "por la tradición", "un capricho". A diferencia de otros contextos urbanos, éste tolera muy bien la ignorancia del preguntón. La tradición se concibe ante todo como una particular forma de relación con una práctica marcada por la fidelidad a lo largo del tiempo. Consiste en comprar los panecillos; cada cual hará luego con ellos lo que guste. Afirma una señora, "Se pone el panecillo con un duro envuelto en un papel dentro de un armario, y no falta el pan ni el dinero en todo el añon.

Con esta laxitud doctrinal contrastan las explicaciones "tradicionalizadoras" del costumbrismo escrito, preocupadas por autentificar la fiesta a partir de sus orígenes. Destacan que el panecillo es recuerdo de aquél que San Antón recibiera del pico de un cuervo durante su estancia como ermitaño en el desierto de la Tebaida; que su fórmula, mantenida en secreto durante siglos, es antiquísima -egipcia o árabe- y permite conservar el alimento durante meses; que era considerado por los romeros como fuente de fortuna ${ }^{9}$. La práctica de los panecillos, es, por tanto, remitida en última instancia al mito hagiográfico, tal y como lo relatara Santiago de la Vorágine en la Leyenda Dorada, y lo representara Velázquez en el cuadro San Antonio Abad y San Pablo, primer ermitaño:

\begin{abstract}
San Antonio, que se había retirado al desierto, tuvo en sus sueños la revelación de que le había precedido otro eremita; se fue a buscarlo, y se tropezó con un centauro y luego con un sátiro, por fin con un lobo (el santo no se extrañaba de esas apariciones, a las que estaba acostumbrado en sus "tentaciones") que, cortésmente, le dirigieron hacia la cueva de San Pablo. Pero éste, queriendo mantener su soledad, se había encerrado con cerrojos. Por fin se decidió a abrir y a la hora de comer apareció un cuervo que le llevaba en el pico doble ración de pan de la de los días ordinarios. Tras la visita, San Antonio emprendió el regreso, pero al ver a unos ángeles que transportaban el alma de San Pablo, volvió a la cueva de éste y lo encontró muerto, pero arrodillado, en actitud de rezar. No sabía cómo excavar su sepultura, pero unos leones le evitaron el trabajo y la hicieron con sus garras ${ }^{10}$.
\end{abstract}

El relato original de La leyenda dorada incluye también una divertida escena de bendición colegiada de ese pan, recibido del cielo:

"Cuando iban a iniciar la comida, surgió entre ellos una piadosa discusión acerca de cuál de los dos, atendida su correspondiente dignidad, habría de bendecir el

9 P. Montoliu, op. cit., p. 38.

10 A Domfnguez Ortiz et al., Velázquez (Madrid: Ministerio de Cultura, 1990), p. 288. 
alimento. Decía Antonio que el honor de bendecir y partir el pan correspondía a Pablo, por ser de mayor edad. Replicaba Pablo:

-Tú eres mi huesped; procede que seas tú quien bendigas y repartas lo que vamos a comer.

Por fin pusiéronse de acuerdo, optando por asir ambos a la vez uno de los panes y tirar de él simultáneamente; $y$, al hacer esto, el pan se dividió en dos partes exactamente iguales" ${ }^{11}$.

La adoración de la reliquia es un acto menor en el conjunto de la fiesta. Sus devotos acuden tras la celebración de las "vueltas" para besarla sobre el altar mayor. Entran en la iglesia con el perro, los niños, las bolsas de panecillos. Dan la reliquia a besar a los críos, o los levantan en vilo. Al irse, miran con devoción la imagen del retablo. Ningún fiel ha sabido decirme qué parte del cuerpo del santo es la que está en el relicario.

Las "vueltas" comienzan a las cinco de la tarde. En la más ancha de estas calles se disponen, desde hace tres o cuatro años, dos estrados de rojo terciopelo. Uno de ellos se destina a las autoridades de la Corporación, y a un animador que va haciendo comentarios por megafonía. En el otro, sobre la acera opuesta, se sube la imagen del santo, rodeada de niños y flanqueada por las jaulas de los perrillos que esa tarde libera el centro municipal de sacrificio de animales abandonados, y que se rifan o entregan a particulares como elemento de la fiesta. Desde ahí el cura parroco, tocado con estola y con el hisopo en la mano, va bendiciendo colectivamente la caravana a su paso.

El año 1992 tuvo lugar de la siguiente manera. El primer animal en ser bendecido fue un espectacular cerdo que cerraba el cortejo en la primera vuelta, y que el padre Villar presentó por la megafonía como «el

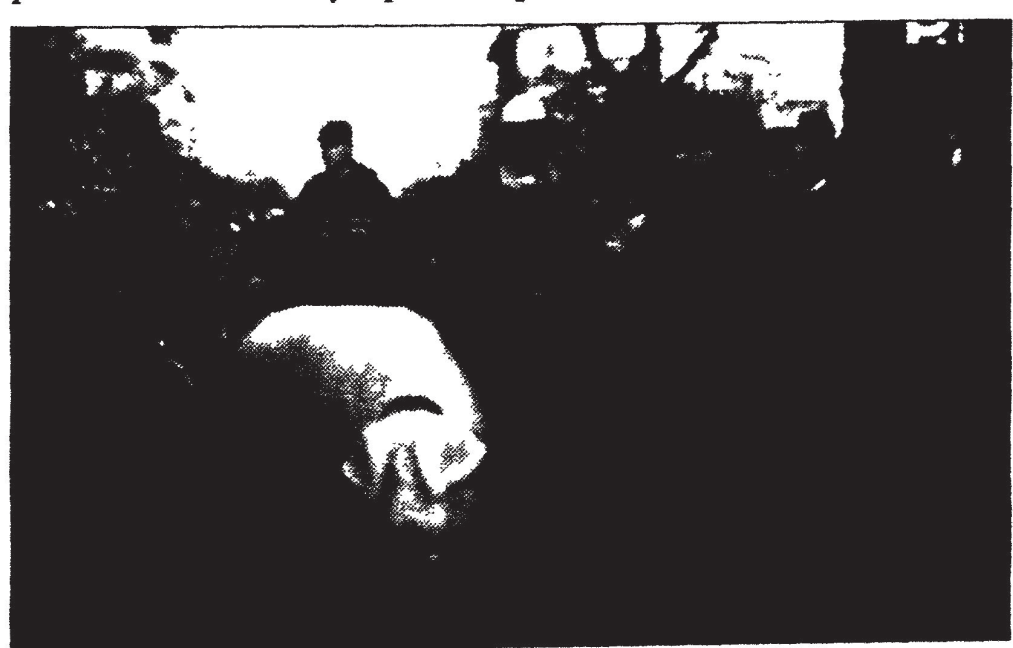
cerdo de San Antón:

"Y ahí, lo mejor que viene, lo mejor que viene no es la pantera negra, ni la pantera rosa, ies el cerdo de San Antón! Ahí le pueden ver... iAl cerdo hay que aplaudirle, ¿eh?, porque es el cerdo de San Antón! A los demás se les mira y se les admira, al cerdo se le aplaude. Ob-

FIG. 3.-El gran cerdo-estrella de la romeria, con su acompañante.

1 Santiago DE LA VORÁGINE, La leyenda dorada. Vol. I. (Madrid: Alianza, 1984), p. 98 . 
serven el cerdo de San Antón, un ejemplar auténtico. Sería cuestión de ver lo largo que es y lo que pesa... Empezamos la bendición de los animales con la del cerdo de San Antón.

El animal - que, asustado por el gentío, reculaba tratando de huirvenía acompañado por un cuidador tocado con sombrero de ala ancha, chaqueta de pana, vara y puro habano, y por un grupo de músicos rurales con chirimías y tambor. Tan pintoresca pareja acude a la romería por lo menos desde el año 1989, si bien en aquel año compartió su protagonismo con el poni, la llama y el camello del Zoo. Además de los niños, asediaban al cerdo los periodistas con sus flashes.

Acto seguido iban pasando ordenadamente a bendecirse las distintas categorías de animales, conducidos por sus dueños, al tiempo que el animador y el párroco los presentaban al público. Primero, los perros antidroga y antiexplosivos de las policías Municipal y Nacional, en formación. A continuación, los perros del Alcalde, quien solicitó ser rociado también con el agua bendita. Explicaba el cura: "Ahora bendecimos los perros del señor Alcalde y de los demás madrileños. El, como primer madrileño; y los demás, como segundos que somos. Al Alcalde no lo bendecimos, porque es un animal racional como todos los demásn. Y como aquél gesticulara en señal de protesta, corrigió, “iHa dicho que también!. Pues para todos. Y añadió: "Las personas también esta mañana han pasado muchas por la capilla del Santo. Para que aprendamos de las virtudes de los animales: fidelidad, lealtad...". Junto con la del "cerdo de San Antón", la imagen de la autoridad bendiciéndose es uno de los temas estrella de la crónica gráfica, por lo que los periodistas se agolpaban a su alrededor, andando de espaldas, cámara en mano.

Detrás iba el común de la gente con sus perros, gatos, canarios, ratones, tortugas... Aunque la bendición fuese colectiva, los romeros querían a toda costa que les cayera el agua encima, con lo que se agolpaban bajo el estrado pese a las protestas reiteradas del animador y el cura. Este

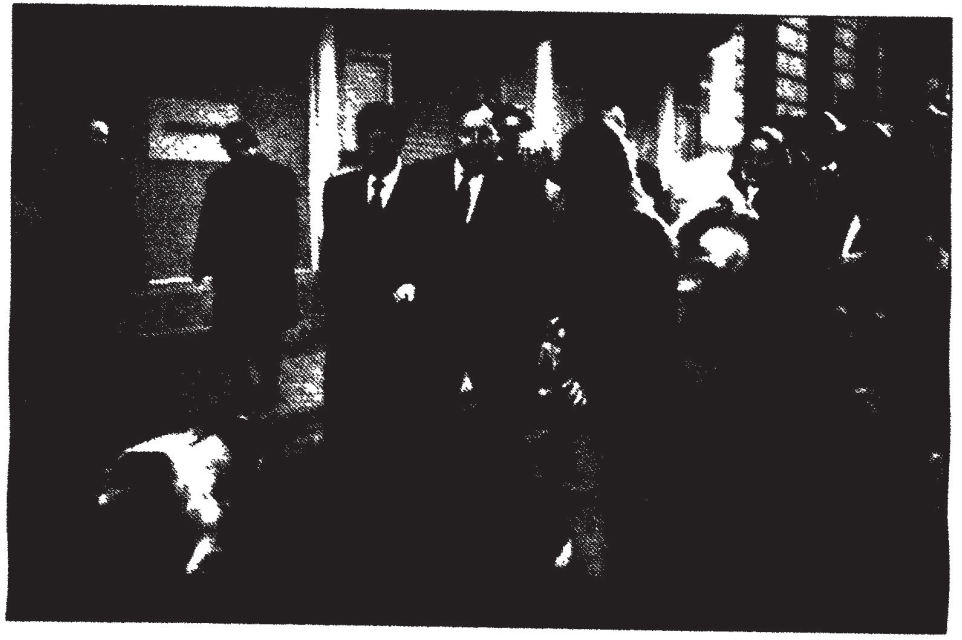
argumentaba que con dar las vueltas ya iban "quedando bendecidos todos". "iCon lo bien que se están portando los animales, a ver si los humanos nos portamos tan bien como ellos!n

Fig. 4.-El alcalde y sus collies. 
Luego, una agrupación de castizos llevaba un pato ataviado con un gran collar. Seguían las bandas de trompetas y timbales a caballo de la Policía y la Guardia Civil, interpretando frente a las tribunas aplaudidos solos de clarín. Coches de caballos de distintos cuerpos del ejercito, montados por chulapos y chulapas. Una jaula con palomas de la Unidad Colombófila del Ejército. Varias cabras del Zoo de la Casa de Campo. Una pantera negra (enjaulada, claro está) del Zoo de Parquegrande.

La tercera vuelta, preceptiva según la tradición, no la dió realmente nadie. Las autoridades ya se habían marchado, los caballos y carrozas fueron descolgándose de la cabalgata poco a poco; y, sobre todo, ya nadie atendía, porque el público se aglomeraba esta vez en torno a los puestos donde un sponsor distribuía alimento para animales gratis. La cebada de antaño ha venido a ser sustituida por latas de Pal para perros, gatos y canarios.

Como cierre del acto, el comentarista invitó así a los participantes a regresar al año siguiente:

Que el año que viene vengan muchos más animales, los animales de verdad; los que están haciendo el animal por ahí que dejen de hacer el animal; y que vengan los animales irracionales aquí, tan buenos y tan magníficos como han venido hoy, sin problemas, sin organizar follones, y como si no fueran unos perros españoles.

\section{REBAJAMIENTOS, INVERSIONES Y COMMUNITAS: TRES SUGERENCIAS INTERPRETATIVAS}

Una vez al año, esta romería focaliza nuestra atención sobre los animales y su mundo de significaciones. Dentro de ese mundo, es lógico que hoy día sean los animales de compañía quienes han cobrado un lugar predominante; pero la cabalgata incluye también otros, evocadores de variadas formas de relación entre hombre y animal. El lugar estelar lo ocupa desde hace unos años ese cerdo que hemos presentado más arriba, y que viene a recrear, en vivo, una antigua imaginería festiva. Su presencia constituye un elemento de continuidad entre la celebración actual y sus presuntos orígenes, conectando entre sí el conjunto de los símbolos: santo, panecillos y animales. Podemos decir con Turner que es un ssímbolo dominante. porque, como vamos a ver, condensa algunos de los sentidos más importantes del ritual. También podríamos decir, parafraseando jocosamente a James Fernandez, que este cerdo "anuda los tiempos" ${ }^{12}$,

12 Sobre la noción de "símbolo dominante, ver Victor TURNER, La selva de los simbolos (Madrid: Siglo XXI, 1980), p. 33. Sobre la operación del ritual sobre los tiempos, 
evocando en mitad de nuestras calzadas de asfalto una ficticia continuidad con el Madrid premoderno en que los puercos aún andaban sueltos por las calles ${ }^{13}$. En cualquier caso, es un útil y suculento pretexto para tratar de hacer visible, a través de él, el abanico de temas implícitos en la etnografía que acabo de exponer.

Desde luego, la fiesta antigua y su ritual de coronación del rey de los cochinos se prestan muy bien a una lectura bajtiniana en términos de ambivalencia, dado que tanto la inversión carnavalesca de la autoridad como la bendición protectora del alimento venían a converger sobre las figuras de San Antón y de su cerdo. Como señaló Bajtín, en numerosas prácticas medievales como la risa pascual, la fiesta de los locos, las diabladas y las parodias sacras, también los personajes y actos sagrados del culto oficial servían como motivo para el regocijo carnavalesco ${ }^{14}$. Esta pauta, calificada de "risa popular" y "realismo grotesco", sería a su juicio característica de toda la cultura popular prerrenacentista. Bajtín define el estilo grotesco como un "sistema de imágenes" que desdibuja las fronteras de las formas vegetales, animales y humanas, subrayando la continuidad entre los seres de un universo en constante proceso. Una tal comprensión carnavalesca del mundo coloca en primer plano lo material, la risa y el cuerpo como principios regeneradores. Por eso su lógica es la del "rebajamiento" y la "inversión", la de poner "el mundo del revés" transfiriendo todas las cosas al lenguaje paródico de lo "bajo" e "inferior*: la tierra, la tumba, las heces, la comida, lo carnal. Pero, nos avisa este autor, hay que cuidarse de ver en ello un sentido crítico-moral de negación e impugnación abstracta, propio del pensamiento moderno y ausente en el grotesco medieval. Lo peculiar de tales injurias, rebajamientos, parodias, inversiones, degradaciones, profanaciones, coronaciones y derrocamientos bufonescos, era su ambivalencia. Degradaban y mortificaban a la vez que regeneraban y renovaban ${ }^{15}$.

Fuera como fuere en la fiesta de los porqueros, lo cierto es que esta idea bajtiniana de la ambivalencia del rebajamiento (la idea de que lo "inferior" pueda ser ritualmente regenerador), es innegablemente sugestiva como punto de partida para el análisis del caso que nos ocupa. Pues también la fiesta que actualmente celebramos consiste en poner en primer

James W. FERnAndez, Persuasions and Performances (Bloomington: University of Indiana Press, 1986).

13. Al parecer, esto fue frecuente hasta el siglo xvil, pese a provisiones en contra desde la época de los Reyes Católicos (cf. P. MONTOLu, op. cit., p. 42).

it Mijail Bajtin, La cultura popular en la Edad Media y el Renacimiento (Madrid: Alianza, 1988) pp. 19 y 72.

15 M. BAJTIN, op. cit., pp. 5-57 
término, como en un "mundo del revés", a esos que ordinariamente aparecen como "inferiores" nuestros (inferiores en la escala evolutiva, e inferiores en la ordenación social del mundo).

Varios conceptos clásicos de la antropología simbólica han tendido también a subrayar e interpretar el hecho de que algunos rituales impliquen una suspensión radical de las normas, jerarquías y modos de comportamiento ordinarios. Durante tal suspensión, acotada temporal y situacionalmente, aspectos de la cultura por lo común negados o subordinados pueden hacerse explícitos, y hasta se prescriben; dejando espacio a la licencia, al sinsentido y el absurdo, al desorden o al simple trastocamiento de roles y fronteras sociales que, fuera del contexto ritual, resultan impermeables. Max Gluckman, por ejemplo, agrupó bajo el término ritos de inversión aquellas ocasiones prescritas en que los principios dominantes de la estructura social y las figuras que encarnan poder y autoridad son temporalmente degradados o depuestos en su status. Frente a los análisis del primer estructural-funcionalismo, proclive a ver en toda conducta expresiva una manifestación directa del orden social, para Gluckman el ritual sirve a la expresión de los conflictos, si bien de una manera sublimada y ordenada. No obstante, "conflicto" no se refiere aquí principalmente a las luchas abiertas o las situaciones normales de competencia entre individuos, sino a adiscrepancias fundamentales entre los principios sobre los que se basa una sociedad"; a incompatibilidades e inconsistencias lógicas y pragmáticas, derivadas de las propias normas estructurales de la organización social (como, por ejemplo, las que genera sobre una esposa zulú la alternativa entre patrilinealidad por un lado y fidelidad al linaje de procedencia por otro). Paradójicamente, la explicitación de tales principios conflictivos por medio de los símbolos y la performance rituales constituiría un mecanismo reparador para asegurar el mantenimiento del sistema. En la visión de Gluckman, los rituales de rebelión desembocan en la restauración renovada del orden ${ }^{16}$.

Yendo más allá en esa misma línea de crítica al estructuralismo, del cual también procedía, Victor Turner acuñó el concepto de communitas para dar cuenta de lo que ocurre en las situaciones rituales que denominó liminales (del latín limen, umbral.). El prototipo de estas situaciones lo constituye la fase de seclusión o segregación de los ritos de paso. Durante ésta los neófitos, desprovistos de su status ordinario, desarrollan intensas relaciones igualitarias entre ellos. Al homogeneizarlos, despojándolos de los atributos que habitualmente los diferencian según su rango, posición, propiedad o rol, y al someterlos a privaciones o estimulaciones extraor-

16 Max Gluckman, Política, derecho y ritual en la sociedad tribal (Madrid: Akal, 1978), pp. 265 y ss. 
dinarias, el ritual desdibuja su identidad secular y les proporciona una experiencia de su propia sociedad distinta de la que caracteriza los vínculos estructurales corrientes, organizados en términos de género, edad, casta, clase, jerarquía u oposición segmentaria. Es a esta particular experiencia de un "vínculo social generalizado" a lo que Turner se refiere con los términos communitas y antiestructura. Communitas no es lo mismo que "comunidad"; ni en el sentido vulgar de una "zona común de residencia", ni en el sentido de la Gemeinschaft de Tönnies y Weber. Es una "fase" o un "estado" del constante proceso dialéctico por el que pasa la sociedad, en cíclica alternancia. Escribe Turner:

Parece como si existieran aquí dos 'modelos' básicos de interrelación humana, yuxtapuestos y alternativos. El primero es el de la sociedad como un sistema estructurado, diferenciado, y a menudo jerárquico de posiciones políticoeconómico-legales con muchos tipos de evaluación que distinguen a los hombres en términos de "más" y "menos". El segundo, que surge de forma reconocible durante el período liminal, es el de la sociedad en cuanto comitatus, comunidad o incluso comunión entre iguales, sin estructurar o rudimentariamente estructurada, y relativamente indiferenciada... ${ }^{\text {" }}$.

Tanto esta communitas como las "inversiones" de Gluckman y la "ambivalencia" de los rebajamientos bajtinianos se dirigen a contradecir cualquier identificación simplista entre los términos "estructura" y "Sociedad. La estructura, producto de unas relaciones sociales objetivadas, es un momento - aunque el de mayor visibilidad - en el proceso más amplio de la vida social, esencialmente dinámico (dialógico", diría Bajtín). Y de hecho, según sugieren algunos autores, la función de muchos rituales residiria precisamente en mostrar, mediante la presentación de paradojas, transformaciones e inversiones, la contingencia del orden vigente. No se trata con ello de que el orden sea impugnado o derrocado, sino de que sea reconocido como tal -como orden a un tiempo posible y necesario. El proceso ritual es paradójico porque nos lleva a darnos cuenta del orden, gracias al desorden. Los rasgos clave de nuestra cotidianidad se hacen perceptibles a través de las imágenes que nos proporciona su suspensión transitoria.

La "cabalgata de los animales", con sus pacíficas vueltas en torno a la parroquia de San Antón, no tiene desde luego el sentido de transgresión

1. Victor TURNER, The ritual process. Structure and Anti-Structure (Chicago: Aldine, 1968), p. 103. La communitas tumeriana conserva no obstante ecos de la Gemeinschaft de Tönnies. Sobre la oposición Gemeinschaft vs. Gesselschaft, véase Louis DuMONT, Ensavos sobre el individualismo (Madrid: Alianza, 1987), pp. 142,147. También Talcott PARSONs, La estructura de la acción social (Madrid: Guadarrama,1968), p. 836. 
radical que se atribuye al carnaval popular de la Edad Media, ni mucho menos la dramática intensidad ceremonial de la circuncisión ritual Ndembu, tal y como Turner la describió. Su forma particular de eficacia simbólica" nos resulta mucho más cotidiana; conjuga la advocación litúrgica a un santo con un sencillo rito religioso para la protección de las bestias. $\mathrm{Y}$ sin embargo, es posible rastrear en aspectos y momentos de la fiesta matices de antiestructuralidad, de ambivalencia y de inversión que la emparentan, siquiera sea lejanamente, con aquellas otras formas rituales.

\section{UN CERDO SINGULAR}

En aras de la claridad expositiva, organizaremos nuestra interpretación distinguiendo analíticamente entre significado operacional, posicional y exegético, tratando artificialmente de desbrozar lo que en la etnografía se ofrece de hecho como una totalidad indisociable. Voy a eludir entrar a fondo en la espinosa cuestión del "significado del significado" de los símbolos rituales, así como en la discusión sobre las condiciones de verificabilidad de cualquier ejercicio hermenéutico sobre los mismos. Baste decir, para nuestros limitados fines, que el ritual parece prestarse poco a lecturas en términos de significado semántico-proposicional, según el modelo de la vieja lingüística seaussuriana. A la inversa, tampoco parece, por definición, reductible a valores púramente estratégicos, pragmáticos, instrumentales. El ritual no es un texto a descifrar; no es exclusivamente expresivo. El ritual no es tampoco una mera cortina de humo irracional y vacía de contenido para otros fines y funciones; no es exclusivamente instrumental. Es performativo, lo cual significa que es, a la vez e indisociablemente, expresivo e instrumental -aunque probablemente sus sentidos carezcan de la transparencia de un discurso esclarecido, y su orientación a fines no se arrogue la sistematicidad de una tecnología ${ }^{1 *}$.

1. El significado operacional hace referencia a los sentidos implícitos en la acción ritual y la manipulación de los símbolos. Como siempre que

18 Sobre la distinción entre significado posicional, operacional y exegético, ver V. TURNER, La selva de los símbolos (Madrid: Siglo XXI, 1980), p. 56, Sobre el debate acerca de la interpretación del significado del ritual, Dan SPERBER, El simbolismo en general (Barcelona: Anthropos, 1988); Jack GoODY, "Against 'Ritual': Loosely Structure Thoughts on a Loosely Defined Topic , en Secular ritual, eds. S. MOORE y B. MYerhoff (Assem: Van Gorcum, 1977), pp. 25-35; Stanley J. TAMBiaH, "A Performative Approach to Ritualn, Culture, thought and social action. An anthropological perspective (Cambridge, Mass.: Harvard U. P., 1985), pp. 123-166; Honorio VELAsCO, "Rituales e identidad: dos teorías y algunas paradojas", Revista de Occidente, Enero 1986, pp. 65-75. 
se habla de "significado" tendemos a entender "significado semánticoproposicionaln, puede parecer a primera vista chocante que se empiece por este nivel pragmático, de uso: qué se hace, quién lo hace, cómo lo hace, con qué cualidad afectiva, con qué resultados... Pero es que no debe olvidarse que la acción simbólica es ante todo acción eficaz, busca alterar de distintas formas los estados del mundo. En términos de Geertz, las representaciones de que se sirve son modelos de la realidad, pero también, $\mathrm{e}$ indisolublemente, modelos para conformarla ${ }^{19}$.

Parece evidente que en la fiesta de San Antón las personas realizan variados actos de integración social con sus animales. El más notorio es, desde luego, la bendición misma, pero no es el único. Al dedicarles un día - su día - se les coloca temporalmente en el centro de la atención, y también espacialmente, al interrumpir el tráfico. En palabras del cura párroco, "Ese día no hay quien moleste a un perro... Porque el perro, es su día, es el amo de la calle. En cierto sentido, la integración consiste en una asimilación antropocéntrica del animal al orden simbólico y social de las personas, del cual la procesión constituye un modelo: yendo en procesión, los animales ejecutan un acto social. Por eso se supone que los dueños acuden, más que nada, en calidad de acompañantes de sus animales, ya sean alcaldes, niños, ancianitas o policías. Los animales van especialmente aseados, sus dueños los llevan sin reparo hasta el interior de la iglesia, y en algunos casos los tocan con adornos o vestidos antropomórficos. Recuerdo por ejemplo haber visto un perro con foulard, y otro con gafas y sombrero.

Con todo, la asimilación no es inmediata, directa. El animal participa de la sociedad sólo a través de su condición de bien, sea como recurso productivo o como animal de compañía. El ritual protector de la bendición permite saltar la barrera que los separa de nosotros: es como si los animales, por pertenecer a una categoría radicalmente distinta de la nuestra, no pudieran asimilarse sin más, y tuvieran que hacerlo por la sagrada intermediación del santo. Cristianizar al animal es una forma más - aunque ejemplar - de socializarlo. La ruptura momentánea de la frontera pone de manifiesto cuán grande es, en realidad, ese salto.

Un segundo aspecto a destacar en el conjunto de acciones del ritual es que esta aincorporación. de los animales a la sociedad supone una forma de igualación por abajo. Es, en esa medida, una fiesta de

19 Clifford GEERTZ, "Religion as a Cultural System", Reader on comparative religion. An anthropological approach, ed. William A. LESSA y Evon Z. VOGT (New York: Harper \& Row, 1979), pp. 78-89. Para una definición clásica de los rituales como actos eficaces", véase Marcel MAUss, Lo sagrado y lo profano", Obras, vol. I (Barcelona: Barral, 1970). 
communitas con los animales. Mientras que en muchos otros rituales de comensalidad son ellos los que sirven de alimento al hombre, en éste hombres y animales comparten un mismo alimento. $\mathrm{O}$ por lo menos alimentos igualmente bendecidos por el santo ( $\mathrm{si}$ bien nadie come las latas de comida para perros, sí hay quien da a sus perros los panecillos de "mojar en el café"). Esta importante dimensión de reciprocidad está reflejada en el mito, que recoge justamente la escena inversa, cuando el cuervo alimentó al santo con un pan venido del cielo. La acción ritual y la leyenda expresan dos momentos de una misma relación de reciprocidad.

Pero donde más claramente podemos observar dicho igualamiento con el inferior es en ciertas bromas y gestos que son, precisamente, los que dan el tono cariñoso, amable y risueño de la celebración: la gente que decide bendecirse junto con su perro; el cura que moja a la concurrencia amenazando con el agua sagrada; la sugerencia metafórica, en fin, de que todos somos animales (incluidos el párroco y el Alcalde, como ellos mismos tratan de hacer constar). De estos pequeños rebajamientos, concebidos también como una "dignificación" del animal, procede el humor levemente carnavalesco de la romería.

2. El significado posicional hace referencia a la naturaleza representativa de los símbolos rituales, su cualidad de funcionar como modelos de. Los símbolos son, por definición, representaciones condensatorias y polisémicas, están en sustitución de un abanico de denotata. Su significado es posicional porque, como destaca Turner, depende del contexto y del momento en que aparezcan dentro del proceso ritual ${ }^{20}$. Dicho de otra manera, los símbolos simbolizan por oposición, a partir de relaciones de contraste, inclusión y analogía establecidas en una red de referencias mútuas.

Una cabalgata de animales no es, como acaso pudiera parecerle a alguien, un espectáculo trivial. Es un llamativo muestrario de alusiones a nuestra relación con otros seres y lo que para nosotros significan, un escaparate vivo que reclama participación en él. La contemplación del animal mueve a actualizar sus significaciones. En algunos casos éstas nos llegan a través de comentarios espontáneos de admiración, cariño o burla. En otros las percibimos sencillamente en gestos y actitudes. Pero de lo que no cabe duda es de que, lo mismo entre nosotros que entre las organizaciones totémicas, los animales siguen siendo "buenos para pensar".

Al margen de cualquier otra connotación de lo porcino en nuestra lengua y nuestra cultura, me gustaría argumentar que la creciente centralidad del cerdo de San Antón en esta fiesta se halla relacionada con

20 V. TURNER, op. cit., p. 56. 
su capacidad para conectar entre sí distintos sentidos de la misma, condensándolos en una sola imagen. En primer lugar, en ciertos momentos de la fiesta el cerdo es escogido sinecdóticamente, como pars pro toto, para denotar el reino animal en su conjunto, y consecuentemente para connotar todos los valores positivos que le son atribuidos a éste por contraste comparativo con el mundo de los seres humanos. Los momentos más visibles de su protagonista papel son el comienzo de la bendición colectiva y la construcción gráfica de la noticia en prensa, que reproduce emblemáticamente el momento anterior. En otros momentos son otros los animales utilizados para construir este peculiar "argumento de imágenes": los inocentes e indefensos cachorros de perro que indulta el ayuntamiento; los leales y serviciales caballos de la polícia; los bellos y exóticos animales del zoo... Pero el cerdo parece funcionar especialmente bien como prototipo. En tanto que token, o caso representativo de su género, se le concede una notoriedad considerable, sirviendo de vehículo a la oposición hombre-animal. Dicha oposición, persistente leit motiv de la celebración, articula un abanico de connotaciones valorativas del tipo siguiente:

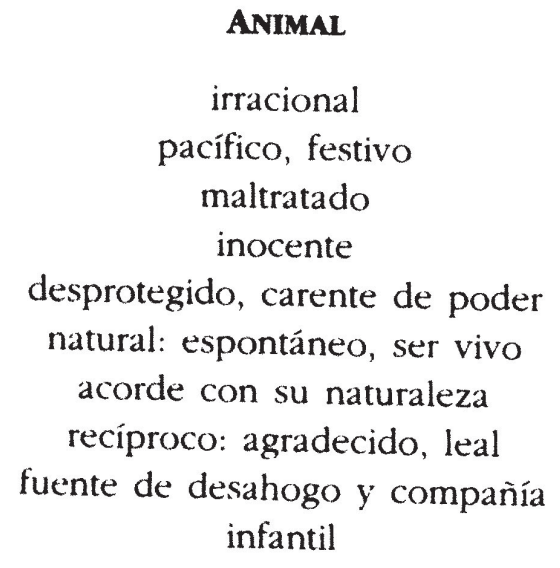

ANIMAL

irracional

acífico, festivo

maltratado

inocente

desprotegido, carente de poder

natural: espontáneo, ser vivo

acorde con su naturaleza

recíproco: agradecido, leal infantil

HOMBRE
racional
violento
maltratador
malintencionado
dominante
no natural: artificioso, maquinal (artificial)
desnaturalizado
interesado
fuente de stress y competencia
adulto

Frente a un mundo envuelto en guerras y violencias, se trata de llamar la atención sobre el carácter pacífico de los animales (y muy especialmente de su fiesta); frente a un ejercicio arbitrario del poder que genera sufrimientos a otros seres vivos, las bestias son "inocentes", vulnerables y carentes de maldad; su "sencillez" y espontánea "naturalidad" se contrastan sistemáticamente con un entorno humano caracterizado por el maquinismo, la artificialidad y la desvinculación de la naturaleza; a diferencia de los hombres, sujetos a los vaivenes de su egocéntrico interés, los animales son "nobles", leales, y permanentemente recíprocos. Y, en fin, suponen un escape del mundo social competitivo y hostil de la ciudad, un depósito de valores básicos. Como los niños, los animales recuerdan a los hombres cosas que contrastan vivamente con su experiencia cotidiana 
adulta (la homologación de niños y animales en virtud de su ainocencia" no es sólo predicada sino también representada, al llenar de niños y cachorros el estrado desde el cual se dan las bendiciones).

No obstante, ese gran cerdo que tan bien ejemplifica la categoría "animal" no es, según nos avisaba el párroco, un cerdo cualquiera. Es uno muy singular. Quiere encarnar al cerdo de San Antón: el mismo que aparece al pie del santo en sus imágenes, y que la gente gusta de ver junto a él. La pareja del santo con su cerdo es de este modo casualmente evocada y actualizada en la procesión -como de hecho lo era también en aquella otra procesión burlesca del rey de los cochinos. A imitación de dicha pareja paradigmática, la "cabalgata de los animales" es en realidad una cabalgata de hombres con sus animales, una cabalgata de pares animal/hombre. Podríamos decir que pone sintagmáticamente en escena la relación modélica entre San Antón y su cerdito, una relación -el mito nos lo dice- marcada por la reciprocidad. Más allá, por tanto, del contraste distintivo entre los animales y los hombres, la evocación del santo preside un sistema de analogias digno de hacer las delicias de cualquier estructuralista, y fundamentado en la relación recíproca, complementaria, entre tipos de animales y tipos de hombres:
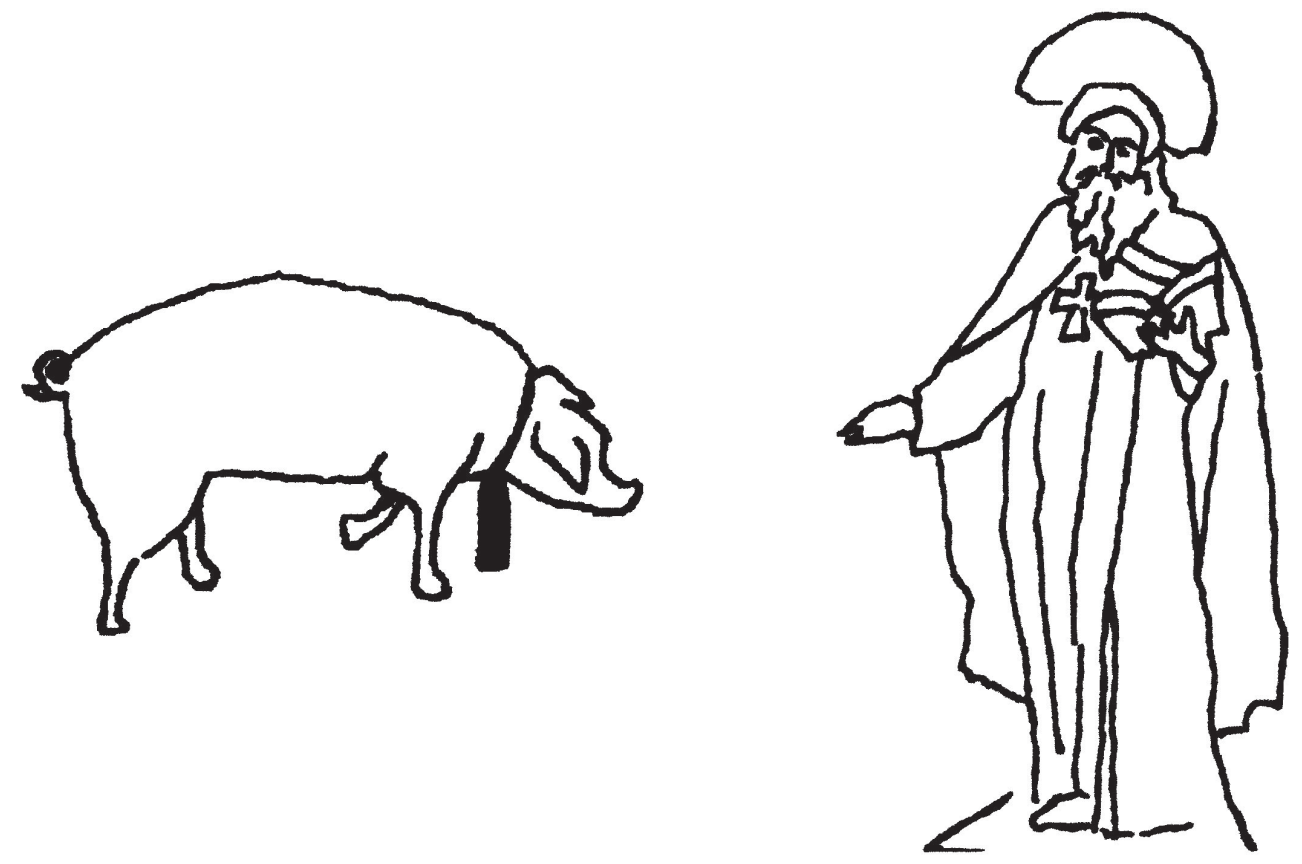

gran cerdo

caballos

camello

ganadero

Policía

Zoo

pato

perros indultados

animales domésticos

(«animal.)

Asociación Castiza

Ayuntamiento

romeros particulares

(abombre.) 
A diferencia de una metáfora atributiva o una mera colección de contrastes entre dos términos, un esquema analógico de este tipo es susceptible de leerse en varias direcciones. Como vimos antes, si comparamos globalmente los términos de la derecha con los de la izquierda, se hacen aparentes las "virtudes de los animales", y destacan sus contrastes con el mundo humano. Pero podemos también leer la columna procesional verticalmente, por parejas. En ese caso lo que destaca es el vínculo que une cada término con su par, y la homología entre todos ellos: el cerdo es a San Antón como los caballos a la Policía y como cada animal de compañía a su dueño. Vistas así las cosas, el cerdo no sólo representa prototípicamente al resto del reino animal; en calidad de "cerdo de San Antón", evoca además metafóricamente la relación recíproca que los hombres mantienen con sus animales. Una relación idealizada en el caso del santo, pero materializada y renovada en la práctica en el caso de los participantes de cada reedición de la fiesta.

Hay que notar que tal homología entre las parejas de términos es sólo relativa. Todas se bendicen bajo la protección del santo, y en esa medida todas se ratifican y sancionan socialmente por igual. Pero responden a variados modos de relación entre hombres y animales. La romería es, no lo olvidemos, una romería urbana, y su muestrario de animales es también un muestrario de las diversas formas de esa vinculación dentro de una sociedad plural. Predominan los animales de compañía de individuos privados que se presentan desagregadamente, como corresponde a una moderna societas estructurada de acuerdo con principios individualistas ${ }^{21}$. Pero existen otras presencias destacables: la de diversas instituciones del Estado como el ejército y la policía, con sus animales "funcionales" al servicio de tareas necesarias para la comunidad; la de los zoológicos y su espectacularización del mundo animal, convertido en objeto de esa actividad peculiar de las sociedades industrializadas que llamamos aocion; pero sobre todo la de ese cerdo agropecuario y rural, acompañado por dulzaineros y un pastor con cayado, propios de un contexto donde el animal es, ante todo, un medio de producción que hay que proteger porque se vive de él. Aunque la romería nos recuerde que la mayoría ya no vivimos de los animales, sino sólo con algunos de ellos, la ciudad permanece abierta en su heterogeneidad a lo que expulsó fuera de sí. El padre Villar, su principal artífice, nos confiesa que lo que él querría traer, realmente, son animales de granja: muchos animales de granja. Y con ello llegamos al último nudo de significaciones asociadas al cerdo; es un animal chocantemente fuera de contexto. Como un recordatorio de lo que fueron

\footnotetext{
21 L. DUMONT, op. cit.
} 
la ciudad y su fiesta, nos remite a un universo tradicional que, siendo nuestro (por tradición), al mismo tiempo ya no lo es (porque hemos cambiado).

3. El significado exegético hace referencia al nivel de la interpretación aindígena", donde Turner nos propone distinguir entre las ainterpretaciones esotéricas" de los especialistas rituales y las "interpretaciones exotéricas" del común de los celebrantes ${ }^{22}$.

Los comentarios espontáneos, sobre el terreno, del público y los participantes en las vueltas pueden agruparse en tres categorías. (a) Algunos son comentarios jocosos, de regocijada impugnación de lo que se está viendo u oyendo, comunes a cualquier contexto festivo: como por ejemplo el muchacho que gritaba «iVivan los burros! ¡Viva la Guardia Civil!» O el que sugería, "Como para tener cuatro o cinco gatos y echarlos con unos cuantos ratones..." (b) En segundo lugar, hay comentarios sobre el desarrollo del acontecimiento que se ofrece en calidad de espectáculo; se admiran los animales llamativos, se aplauden las ejecuciones musicales; se ríen las ocurrencias del animador. (c) Las más interesantes son las interacciones entre personas mútuamente desconocidas a propósito del animal: «Qué lindo es, qué ojillos tiene». "Es muy bueno, sólo que está un poco nerviosom. Forman parte, junto con las caricias a los animales propios y ajenos, de un incremento del contacto social por intermedio de aquéllos.

La paradoja de esta fiesta consiste así en el hecho de que la communitas con los animales genere también, y sobre todo, communitas entre las personas. La fiesta humaniza al hombre al celebrar la humanidad en sus animales; moraliza la vida social, al proteger la vida animal y usarla como pretexto para pensar la sociedad. Así lo explica su principal organizador:

Es una fiesta de amistad. ¿Por qué? Porque nadie pinta ahí nada, el único que pinta es el animal. Entonces, la gente, al darse cuenta de lo que puede significar el animal en la vida, el animal como compañero, como animal doméstico, la gente... no es que se sublime, ni que se le valoricen sus valores humanos, pero que... realmente aporta un algo dentro de sí... Madrid deja de ser un día al año la ciudad pues, del asfalto y... de todo, y se convierte un poquitín en más humana. iA base de los animales, que es lo ridículo! Se convierte en más humana a base de los animales, que no es porque seamos más humanos entre nosotros, sino porque ese día, jah, ah!...

22 V. TURNER, op. cit., p. 56. 


\section{ANTROPOLOGÍA DE LA SOSPECHA E IMPORTANCIA DE LAS ROMERÍAS}

Escribía con mucha ironía Néstor García Canclini que los antropólogos entran en las ciudades a pie, los sociólogos llegan en coche y por la autopista principal, y los comunicólogos en avión. De modo que ven, en una misma ciudad, tres ciudades bien distintas.

El chiste me parece iluminador; no sólo porque sea cierto que la realidad de la ciudad es pluriforme (puede ser descrita de muchas maneras y desde muchos puntos de vista); sino ante todo porque caricaturiza las distintas inercias a las que ha obedecido cada tradición de investigación social a la hora de construir su objeto en el contexto de la ciudad. Los antropólogos, por ejemplo, han tendido a reproducir en ella las "islas culturales" desde las cuales los clásicos fundamentaron su modo de hacer y las técnicas del trabajo de campo. Han buscado comunidades (étnicas, religiosas, residenciales), corporaciones (grupos bien definidos, con fronteras culturales comunes, como por ejemplo ciertas categorías socioprofesionales), barrios... También se han servido de nociones como "cultura popular" para acotar un recinto de observación: prácticas simbólicas ligadas a la identidad colectiva, al sentido de tradición, a la continuidad social de los grupos. Esto se hizo muchas veces, y se hace, a costa de pasar por alto la maniobra política de esa acotación, e implicando un cierto grado de "folclorización" del objeto (pues no hay "cultura popular" sino por su exclusión de la "cultura culta", que es la que en definitiva demarca sus límites). El resultado de todo ello es la tendencia a hacer antropología en la ciudad más que una antropología de la ciudad. Una antropología más centrada en su periferia que en sus centros (periferia en un sentido social - grupos marginales y minorías étnicas-; pero también periferia en cuanto al tipo de conductas escogidas para estudio - por ejemplo, dejando fuera el mundo laboral, las tomas de decisión de las organizaciones, las interioridades de la trama de relaciones políticas y económicas formalizadas de la que la ciudad es laboratorio-). Una antropología en ocasiones idealizadora de ciertas formas culturales ("populares" y "locales") en contra de otras ("modernas" y "universales"). Todos estamos acostumbrados a ver etnografías en las que apenas hacen aparición la televisión o la radio, la relación con el consumo, las escuelas y las neveras ${ }^{23}$.

23 Nestor GARCIA CANCLINI, Culturas bibridas. Estrategias para entrar y salir de la modernidad (México: Grijalbo, 1989), p. 16; Joan PRAT, J. "Reflexiones sobre los nuevos objetos de estudio en la Antropologia española", Los españoles vistos por los antropólogos, coord. María CATEDRA (Madrid: Júcar, 1986); Eunice DURHAM, «A pesquisa antropologica com populaçoes urbanas: problemas e perspectivas", $A$ aventura antropologica. Teoría e pesquisa, ed. Ruth CARDoso (Río de Janeiro: Paz e Terra, 1986), pp. $17-37$. 
Por otro lado, el chiste acusa a los sociólogos de haberse preocupado por los fenómenos de la urbanización sólo en tanto que síntomas de modernización, y de haber pasado por alto cuanto en la cultura de las ciudades no se ajusta o no cabe en un autoconcepto ilustrado de la sociedad, moderno, modernista y modernizador. Por expresarlo en una jerga weberiana, lo que escapaba o resistía al proceso de racionalización de la vida social, al "desencantamiento del mundo", no era más que "supervivencia", "resistencia" o "residuo"; algo que con el tiempo habría de morir (aunque Honorio Velasco nos ha hecho notar que la acultura popular" lleva ya dos siglos muriéndose, sin llegar a morirse nunca ${ }^{24}$ ). El culmen de tal tendencia modernocéntrica lo constituiría precisamente un cierto tipo de análisis de la "cultura de masas" que se concentra exclusivamente en la estructura de los medios y la industria cultural como estrategia para diagnosticar todo lo que ocurre en la sociedad. Como si tales fenómenos no pasaran por lecturas, rediseños y adaptaciones propias de las culturas locales. Como si existiera un lugar de privilegio desde el que realmente se pudiera ver "todo lo que ocurre en la sociedad" ${ }^{25}$.

En un mundo sin islas culturales, sociólogos y antropólogos afrontan el problema del desdibujamiento de sus objetos de estudio, y de las hibridaciones que desde la propia realidad empírica ponen en cuestión distinciones convencionales entre lo "popular"/lo "culton/lo "masivo", lo "moderno"/lo "tradicional", y otras distinciones similares que justificaban los especialismos en el tratamiento de distintas facetas de la cultura urbana. El proceso de globalización generado en las raíces mismas de la modernidad, con sus pretensiones universalizadoras —continúa el argumento de García Canclini- no debe ser entendido como una ineluctable homogeneización y nivelación de todas las diferencias, sino más bien como su rearticulación en un sistema más amplio que las absorbe, subordinándolas y emborronando los límites entre ellas. Así, nos cuenta el autor, los artesanos purépechas de Ocumicho (México) representan hoy a sus tradicionales diablos de barro montados en motos y aviones; o incluso utilizan temas de grabados de la Revolución Francesa, obedeciendo a un encargo museístico que les vino desde el otro lado del océano. Y acaba ironizando:

24 Honorio Velasco, "Los significados de Cultura y los significados de Pueblo. Una historia inacabada. Comunicación y Movimientos Sociales, ed. Carmen CAFFarel et al. (Ciudad Real: Imprenta provincial, 1994), pp. 37-61; Michel DE CERTEAU, Dominique Julia y Jacques REVEL, "La beauté du mort. Le concept de 'culture populaire', Politique aujourd'bui, Dic. 1970.

25 Para una crítica antifuncionalista de la teoría de los medios de comunicación masiva, ver los trabajos de Jesús MARTín-BARBERo, De los medios a las mediaciones. Comunicación, cultura y hegemonía (México: G. Gili, 1987). 
-Parece que los antropólogos tenemos más dificultades para entrar en la modernidad que los grupos sociales que estudiamos“ ${ }^{26}$.

Y bien, objetará el lector llegado este punto. ¿Es que no es ése mismo su caso? ¿No será en realidad el "cerdo de San Antón" semejante a dichos diablillos en sidecar: un producto híbrido que conviene contemplar también, y antes que nada, desde la perspectiva de su pertenencia a la modernidad? ¿No habría tal vez que plantearse, en lugar de tanto análisis de símbolos, la hipótesis nula de que todo ese asunto de las fiestas de Madrid no sea más que "pan y toros" (o "pan y calleja", como decían antiguamente), un puro intercambio instrumental entre instituciones deseosas de legitimarse y ciudadanos sedientos de espectáculo? Una visión, por otra parte, frecuentemente defendida desde la prensa, y desde algunas instancias de la propia institución municipal. ¿Dónde está la especificidad urbana de la anterior descripción? Y, más profundamente, ¿en qué medida pueden rituales como la bendición de los animales ser "urbanos" y "modernos??

Dado que son éstas -y no otras- las preguntas que constantemente yo mismo le hago a mi etnografía, sería una osadía por mi parte que tratara de darles en este lugar una respuesta acabada. Me conformaré con esbozar algunas direcciones de análisis complementarias a la que hasta aquí he seguido, señalando a modo de ejemplo dos puntos importantes en los que creo que se desvía de las asunciones implícitas en otras descripciones "estándar", por así llamarlas, del trabajo simbólico del ritual en contextos "tradicionales" de investigación. En dichas descripciones, de las que las etnografías habituales de cualquier romería rural representarían un prototipo, suele darse por supuesto 1) que el horizonte social por excelencia del ritual es el de las relaciones de comunidad; 2) que la tradición proporciona el programa de acción colectiva definitorio del ritual, las guías apropiadas de conducta para quienes participan en él.

1. ¿Quién es el sujeto de la romeria? Desde un punto de vista objetivo, resultaría difícil mantener la ficción de que el protagonismo festivo de la fiesta de San Antón corresponde a una comunidad; ni en un sentido territorial estricto, ni en el sentido más profundo de un modo de vinculación holista entre los sujetos participantes como miembros de un todo orgánico ${ }^{27}$. Distintos organizadores tienen en mente referencias variables

26 N. Garcla Canclini, op. cit., p. 200 y ss.

27 En la caracterización que Parsons hace de las relaciones de Comunidad (Gemeinschaft) frente a las de Sociedad (Gesellschaft), para las que toma como ejemplo las relaciones familiares, destaca el ser "una relación más amplia de solidaridad sobre un área general bastante indefinida de vida e intereses" en la que, a diferencia de ésta, nunca se trata de un objetivo limitado y específico. (T. PARSONS, op. cit., p. 839). 
a los fieles de la parroquia, a los vecinos del barrio, a los vecinos del distrito y a los ciudadanos de la ciudad. En su desarrollo observamos un abanico de posibles posiciones de participación: como organizador, romero, espectador interesado, observador casual, sufridor del embotellamiento del tráfico... El primer problema que plantea por tanto cualquier fiesta madrileña a sus gestores ( $\mathrm{y}$, por ende, a periodistas y antropólogos) es saber quién es su "público", y hasta qué punto va a estar dispuesto a "participar" en ellas.

La paradoja, no obstante, reside en que la organización centralizada y coordinada de los actos durante la fiesta proyecta sobre la congregación de celebrantes una imagen de comunidad, por ficticia que sea. En consecuencia se podría decir que la comunidad existe sólo por la fiesta, en tanto dura la fiesta. La comunidad es, más que un vínculo real, el resultado de un "pacto de lecturan. Es sobre todo una comunidad "hermenéutica", capaz de movilizarse a partir de un consenso sobre símbolos por encima de las fronteras sociales y de intereses que, de ordinario, separan a los sujetos que la componen ${ }^{28}$.

2. ¿Cuál es el lugar de la tradición en la fiesta? Varios datos ilustran el hecho de que la tradición es una guía de comportamiento insuficiente en el contexto de esta celebración; lo cual resulta muy natural si se tiene en cuenta que desde los años sesenta se había dejado de celebrar. En 1989 , las vueltas no se pudieron llegar a terminar porque la mayoría de los romeros prefirió adoptar la actitud prevenida de ver la procesión, y luego tratar de conseguir llegar a la capilla por su cuenta para obtener la bendición de su animal a título particular. Se montó una buena zapatiesta en la calle: los caballos no podían pasar, los perros ladraban, y el cura párroco acabó recriminando a los participantes su falta de respeto a San Antón. El año 1991 llovía. Sobre su podio, y ante la desbandada general, el locutor pedía ayuda a la organización: «Bueno, que alguien me diga cuántas vueltas son y lo que tengo que decir!» Pregunté con malicia a uno de los organizadores municipales si sabía cuantas vueltas había que dar. "Si se sigue la tradición, tienen que ser cinco", me respondió. "Pero con esta lluvia no sé si se harán.... Casi todo el mundo se fue durante la segunda, siguiendo el ejemplo de las autoridades.

Con esto damos en una nueva paradoja: la tradición es mediada por instituciones universalistas (cuya autoridad, por contraste, no se presenta como "tradicionaln). La tradición es parte de un "programa" (esto es, de un ejercicio de ordenación racional) concebido, gestionado y ejecutado por distintos tipos de mediadores. Ya he destacado el lugar de las fuentes

\footnotetext{
28 Cf. N. García Canclini, op. cit.
} 
librescas en esta mediación: los que quieren "reverdecer las costumbres" han de guiarse para ello, entre otras cosas, por reconstrucciones letradas que estipulan lo que la tradición era y significaba en tiempos precedentes. Recientemente algunos antropólogos han prestado atención al efecto autoritativo y sancionador de estas reconstrucciones sobre las prácticas mismas ${ }^{29}$. En segundo lugar, la institución política considera la fiesta un bien público y un campo legítimo de su actuación. Su posición es inevitablemente ambigua, en la medida que, en una sociedad democrática, servirse de la tradición para legitimarse ante los ciudadanos implica también someterse públicamente a ella (mi ejemplo preferido para mostrar esto es la Cabalgata de Reyes, en la que tres concejales del Ayuntamiento disfrutan el extraño privilegio de ser por un día reyes de Oriente). Por eso la gestión "técnica" nunca puede llegar a empañar el hecho de la existencia de "políticas de la tradición" que la respaldan. En tercer lugar, ¿cómo no interrogarse por el papel mediador de la iglesia? La figura del párroco que la encarna ha sido y es crucial en todo el proceso, buscando enganches y soportes institucionales que aseguren su continuidad; destacando el lado "simpático" y "amable" del evento; tratando de promocionar su imagen; seleccionando las lecturas válidas de la devoción al santo, en contra de "fetichismos" y "tribalismos" a su juicio exagerados.

Por último, los medios de comunicación masiva tienen un papel nada desdeñable en la preparación y construcción del acontecimiento. En términos generales, tienen el efecto de textualizar las actividades del ritual, en dos sentidos diferentes: a) ponen las acciones en discursos que las interpretan, y las hacen comprensibles como mensajes unívocos a una audiencia amplia. Por dar un ejemplo, la composición del Villa de Madrid de enero de 1992 hacía de la fiesta un acto de defensa ecológica, al colocarlo bajo otra noticia sobre el gamberrismo contra los gatos en un parque de Ciudad Lineal. La crónica de San Antón rezaba, consecuentemente: "Todavía hay quien quiere a los animales". b) Acentúan la dimensión externa de la actividad frente a su sentido interno para los propios celebrantes, tendiendo a que se enfaticen en la ejecución aquellos momentos susceptibles de ser ofrecidos a receptores lejanos como espectáculo visual, y que condensan la intencionalidad comunicativa de los participantes de puertas para afuera.

$\mathrm{Y}$ así, se hace evidente que nuestro cerdo es recreación moderna y mediata de una imaginería costumbrista. Ahora bien, ¿cómo han de ser entendidos estos usos modernos de la tradición? ¿Significa la einvención de

29 Por ejemplo, Jane K. Cowan, *Folk truth: when the scholar comes to Carnival in a 'traditional' community", Joumal of Modern Greek Studies 6, 1988, pp. 245-59. 
tradiciones" (como quiera que ésta sea definida) una simple y llana instrumentalización por parte del poder del capital de consenso contenido en los símbolos? ¿Habrá que pensar que la modernidad es algo así como el grado cero de la vida simbólica? Mi visión sería más bien la contraria: que en las complejas relaciones entre distintos modelos de mediación la tradición "se cuela", por decirlo de algún modo, por las rendijas de la racionalización institucional, presentándose como un modelo implícito, y extraordinariamente eficaz, de continuidad social y de integración conductual. Dicho en otros términos, proporciona pautas allí donde de lo que se trata es de poner a la gente junta a hacer cosas. La tradición como proceso implica siempre mediaciones que la instrumentalizan; sólo una visión estática y muerta de las culturas tradicionales nos ha permitido ignorar a cuantos la interpretaban, recreaban, inventaban, rehacían y confundían en el proceso mismo de su apropiación y transmisión. Lo cual no significa que la cultura, en el sentido en que los antropólogos usamos el término, pueda someterse enteramente a un diseño de fines racionalmente estipulados. A diferencia de la memoria instrumental - ha escrito Martín-Barbero- la memoria cultural "no es la memoria que podemos usar, sino aquella otra de la que estamos hechos" ${ }^{30}$.

A mi juicio, las dificultades para hacer trabajo de campo urbano desde una perspectiva simbólica tienen que ver, precisamente, con esta imposibilidad de desimbricar la madeja de varias lógicas diferentes que se dan siempre juntas, y de hacer comprensible a los informantes lo que buscamos en ellas. La conexión de la acción simbólica con un organum de creencias sistematizadas y trascendentes, que caracterizó en sus orígenes al concepto de ritual en el ámbito de la historia de las religiones, ha pasado a tener para los que investigamos en este contexto el status de una mera sospecha: la de que en determinados comportamientos se da algo más que el puro actuar con arreglo a metas, sin que en la mayoría de los casos sepamos muy bien especificar de qué se trata. Consecuentemente, todo el trabajo de la antropología urbana, en tanto que una "antropología en casa", deviene un ejercicio sistemático de desconfianza o sospecha, en múltiples direcciones. La gente sospecha del antropólogo, porque no

30 J. MARTín-BARBERo, op. cit., p. 200. Sobre la dimensión externa" del ritual como mensaje dirigido a 'Otros", ver Gerd BaUmanN, "Ritual implicates 'Others': rereading Durkheim in a plural society", Understanding Rituals, ed. Daniel DE COPPET (London: Routledge, 1992), pp. 97-116. Sobre la invención de tradiciones, Eric HOBSBAwм y Terence RANGER (eds.), The invention of tradition, (Cambridge: Cambridge University Press, 1983). Para un análisis de los numerosos cambios en las mediaciones de la cultura popular en Europa, ver Peter BURKE, Popular Culture in Early Modern Europe (New York: Harper \& Row, 1978). 
entiende qué demonios quiere, ni cuáles son sus intereses como estudioso, ni mucho menos dónde está el interés de lo que estudia. El antropólogo sospecha de su propio trabajo, en el que ve permanentemente las huellas de una disciplina que lo marca para el cultivo de lo que no parece sino "capricho": lo marginal, lo tradicional, lo residual, lo anacrónico, lo fútil. Sospecha para colmo de la cultura que estudia -que es la suya propia-, ciega para percibirse a sí misma con los ojos del antropólogo, e ingenuamente pagada de su racionalidad y su transparencia.

Tengo que terminar haciendo la salvedad de que no considero estos matices contradictorios, sino complementarios del tipo de análisis que presenté al comienzo: por tanto, necesarios para resituarlo en su correcta dimensión. Una dimensión que, sin llegar a ser la de muchas romerías rurales, tampoco se corresponde con la visión ingenuamente racionalizada e iluminista con que las instituciones dominantes de nuestra sociedad (comenzando por la institución científica) tienden a concebirse a sí mismas, etnocéntricamente, en términos utilitaristas de "razón práctica". Al estudiar "símbolos en la ciudad", lo que tenemos delante no es ni mucho menos un abstracto y unidimensional bomo aeconomicus ocupado en maximizar la racionalidad de sus cálculos y estrategias. Ni tampoco unas instituciones devoradas por la «jaula de aceron de su propia lógica burocrático-instrumental, sustraídas a cualquier sentido de tradición local y de memoria cultural. Es cierto que los ámbitos diversificados de la política, la economía, el arte, la ciencia y el derecho (que la modernidad se ha ocupado de ir autonomizando de modo irreversible) son el espacio de una poderosa presión racionalizadora, donde hablar de acción simbólica, no digamos de ritual, puede sonar oscuro, periférico y fuera de lugar (y, de hecho, puede serlo en numerosas ocasiones). Pero haríamos un mal negocio si, para llevar la antropología a esos ámbitos, largamente apropiados por otras disciplinas dentro de las ciencias sociales, olvidáramos los beneficios de nuestra propia tradición; sintiendo la tentación de adscribirnos, también nosotros, a una concepción exclusivamente estratégica de la cultura ${ }^{31}$.

La primera vez que fuí a un congreso de antropología, viniendo como vengo de una ciencia que se reclama más «dura y positiva que ésta (la psicología), me pregunté por qué los antropólogos hablaban tanto de

31 Acerca de la autoconcepción de la modernidad en términos estratégicos de Razón práctica, Marshall SAHLINS, Cultura y razón práctica (Barcelona: Gedisa, 1988); Jurgen HABERMAS, Teoria de la acción comunicativa. Complementos y estudios previos (Madrid: Cátedra, 1989); Angel DIAZ DE RADA y Francisco CruCES, "Los 'misterios de la encarnación': algunos problemas en torno al lenguaje analítico de la práctica, Endoxa 1, 1992, pp. 287-308. 
fiestas y romerías. Aquello me parecía poco serio para hacer teoría; peligrosamente parecido al desprestigiado sfolclore" y a la retórica populista de los políticos en torno a "la autenticidad y "las raíces". Hoy, pocas cosas me fascinan tanto como tratar de hacer el autoanálisis del etnocentrismo contenido en esa retórica de la que somos, querámoslo o no, juez y parte. Cuando la gente nos atribuye un interés coleccionista por los orígenes y por la tradición, los jóvenes antropólogos, ilustrados entre los ilustrados, torcemos el ceño. Ese prejuicio nos resulta demasiado familiar; se halla en los orígenes evolucionistas de nuestra disciplina. Querríamos demostrar socialmente que podemos estudiar cosas más "serias".

Hay que argumentar al revés, como precisamente algún sociólogo viene haciendo ${ }^{32}$. Estas son cosas serias, tal y como las estudiamos; pero sobre todo tal y como la gente las vive; tal y como las instituciones luchan por apropiárselas; tal y como posibilitan contemplar la vida moderna de un modo alternativo al estrecho autoconcepto ilustrado e iluminista de la modernidad. El que estemos sujetos a símbolos resalta que nuestra condición es una más, entre otras muchas, de todas las formas de cultura y de tradición. Por eso he tomado como excusa, para argumentar en favor del estudio del ritual urbano, una hermosa e intrascendente romería: para que sirva de homenaje a algunos de mis predecesores y maestros, que también las estudiaron y las estudian; para que se divierta el lector, que buena falta hace... Y para que nos bendiga a todos San Antón.

\section{BIBLIOGRAFIA UTILIZADA}

AZORÍN, F. (1984): El Madrid devoto y romero. Madrid: El Avapiés.

BAJTIN, M. (1988): La cultura popular en la Edad Media y el Renacimiento. Madrid: Alianza.

BaumanN, G. (1990): -Rituals directed at others. EASA I Conference, Coimbra.

BoIsSEvaIN, J. (ed.) (1992): Revitalizing European Rituals. London: Routledge, EASA Monographs.

BURKE, P. (1978): Popular Culture in Early Modern Europe. New York: Harper \& Row. CARo Baroja, J. (1986): El carmaval. Análisis bistórico-cultural. Madrid: Taurus.

Cowan, J. K. (1988): "Folk truth: when the scholar comes to Carnival in a "traditional" community. Journal of Modern Greek Studies 6:245-59.

De Certeau, M.; Julia, D.; Revel, J. (1970): .La beauté du mort. Le concept de 'culture populaire'. Politique aujourd'bui, Dic.

DE LA VORÁGINE, S. (1984): La leyenda dorada. Vol. I. Madrid: Alianza.

DíaZ DE RADA, A.; Cruces, F. (1992): -Los 'misterios de la encarnación': algunos problemas en torno al lenguaje analítico de la práctica. II EASA Conference, Praga.

32 Por ejemplo Enrique Gil Calvo, Estado de fiesta (Madrid: Espasa Calpe, 1990). 
Dominguez Ortiz, A. et al. (1990): Velázquez. Madrid: Museo del Prado, Ministerio de Cultura.

DUMONT, L. (1987): Ensayos sobre el individualismo. Madrid: Alianza.

DURHAM, E. (1986) "A pesquisa antropologica com populaçoes urbanas: problemas e perspectivas" (17-37). A aventura antropologica. Teoría e pesquisa. CARDOSO, R. Río de Janeiro: Paz e Terra.

FERnÁNDEZ, J. (1986): Persuasions and Performances. Bloomington: University of Indiana Press.

GarCia CANCLINI, N. (1989): Culturas bíbridas. Estrategias para entrar y salir de la modernidad. México: Grijalbo.

GEERTZ, C. (1979): "Religion as a Cultural System». (78-89) Reader on comparative religion. An anthropological approach. LESSA, W. A.; VOGT, E. Z. New York: Harper \& Row.

Gil Calvo, E. (1991): Estado de fiesta. Madrid: Espasa Calpe.

Gluckman, M. (1978): Política. derecho y ritual en la sociedad tribal. Madrid: Akal.

GOODY, J. (1977): "Against 'Ritual': Loosely Structure Thoughts on a Loosely Defined Topic. (25-35) Secular ritual. MOORE, S.; MYerhoff, B. (eds.) Assem: Van Gorcum.

Habermas, J. (1989): Teoría de la acción comunicativa. Complementos y estudios previos. Madrid: Cátedra.

Hobsbawm, E; RANGer, T. (eds) (1983): The invention of tradition. Cambridge, Cambridge University Press.

MARTÍN-BARBero, J. (1987) De los medios a las mediaciones. Comunicación, cultura y hegemonía. México: G. Gili.

MAuss, M. (1970). "Lo sagrado y lo profano". Obras, vol I. Barcelona: Barral.

MONTOLIU, P. (1990) Fiestas y tradiciones madrileñas. Madrid: Sílex.

PARSONS, T. (1968) La estructura de la acción social. Madrid: Guadarrama.

PRAT, J.: "Reflexiones sobre los nuevos objetos de estudio en la Antropología española". Los españoles vistos por los antropólogos. CaTEdRA, M. (Coord.) Madrid: Júcar.

ROSAlDO, R. (1986): "Ilongot Hunting as Story and Experience". (97-138) The anthropology of experience. V. W. TURNER; E. M. BRUNER (eds.) Urbana y Chicago: University of Illinois Press.

SAHLINS, M. (1988): Cultura y razón práctica. Barcelona: Gedisa.

SPERBER, D. (1988): El simbolismo en general. Barcelona: Anthropos.

TAMBiaH, S. J. (1985): "A Performative Approach to Ritual". (123-166) Culture, thought and social action. An anthropological perspective. Cambridge, Mass.: Harvard U. P.

TuRner, V. (1968): The ritual process. Structure and Anti-Structure. Chicago: Aldine. (Hay traducción española: (1989) El proceso ritual. Madrid: Taurus).

TURNER, V. (1980): La selva de los simbolos. Madrid: Siglo XXI.

Velasco, H. (1986): "Rituales e identidad: dos teorías y algunas paradojas". Revista de Occidente, Enero: 65-75.

Velasco, H. (1994): "Los significados de Cultura y los significados de Pueblo. Una historia inacabada. Comunicación y Movimientos Sociales, ed. Carmen Caffarel et al., Ciudad Real: Imprenta Provincial.

FRANCISCO CRUCES

UNED. Madrid 
San Antón, patrón de los animales, es celebrado en el barrio de Hortaleza de Madrid con una peculiar romería. Perros, gatos, y otros animales domésticos dan tres vueltas alrededor de la antigua parroquia del Santo en amable cabalgata, recibiendo la bendición del cura "para que los libre de todo mal. La celebración, revitalizada a comienzos de los ochenta tras décadas de abandono, implica desde luego una recreación moderna de la imaginería costumbrista, pero también la vigencia y el poder evocativo de formas simbólicas y modelos tradicionales de acción y representación. En la vida de la ciudad moderna, los animales siguen siendo "buenos para pensar".

The festivity of San Antón, patron saint of the animals, is celebrated in the neighbourhood of Hortaleza (Madrid) with a singular pilgrimage of pets around the parish. Cats, dogs and other domestic animals are brought to the streets in a kindly parade, to be blessed by the parish priest. This celebration was revitalized at the beggining of the 80's after decades of abandonment. We can find in it both a modern recreation of an ancient imagery and, conversely, the persistence of the evocative power of symbolic forms and traditional models of action and representation. In modern urban life, animals still are "good to think". 